\title{
Environmental Fate and Effects of Bacillus thuringiensis (Bt) Proteins from Transgenic Crops: a Review
}

\author{
Bryan W. Clark, Todd A. Phillips, and Joel R. Coats** \\ Pesticide Toxicology Laboratory, Department of Entomology, Iowa State University, Ames, Iowa 50011
}

\begin{abstract}
This paper reviews the scientific literature addressing the environmental fate and nontarget effects of the Cry protein toxins from Bacillus thuringiensis (Bt), specifically resulting from their expression in transgenic crops. Published literature on analytical methodologies for the detection and quantification of the Cry proteins in environmental matrices is also reviewed, with discussion of the adequacy of the techniques for determining the persistence and mobility of the Bt proteins. In general, assessment of the nontarget effects of Bt protein toxins indicates that there is a low level of hazard to most groups of nontarget organisms, although some investigations are of limited ecological relevance. Some published reports on the persistence of the proteins in soil show short half-lives, whereas others show low-level residues lasting for many months. Improvements in analytical methods will allow a more complete understanding of the fate and significance of Bt proteins in the environment.
\end{abstract}

Keywords: Environmental fate; Bt proteins; transgenic crops; nontarget effects; Cry protein

\section{INTRODUCTION}

Bacillus thuringiensis (Bt) is an aerobic, Gram-positive, sporeforming soil bacterium that produces insecticidal crystal proteins. The spores and protein crystals from Bt have been used as microbial insecticides for over 40 years (1). The crystal toxins are designated by the term Cry and a combination of letters and numbers indicating family and subfamily (e.g., Cry1Ab, Cry1Ac, Cry3Bb, Cry3A). The different strains of the bacterium produce various combinations of Cry protein toxins, which are considered to be selective and to generally target insects of a specific order. For example, Cry1, Cry2, and Cry9 proteins are active against the Lepidoptera (moths and butterflies), Cry3 proteins are active against the Coleoptera (beetles), and Cry2 and Cry4 proteins are active against Dipterans (including mosquitoes and black flies). In some of the older literature, the authors will reference the subspecies of Bacillus thuringiensis from which the toxin used came, i.e., Bt kurstaki or $\mathrm{Bt}$ israelensis. Unfortunately, because of this convention and the fact that some of the subspecies can produce multiple crystal toxins, it is not always certain which crystal toxin is referred to in the older literature.

The mode of action of $\mathrm{Bt}$ proteins is not completely understood; in general, the protein is solubilized and activated in the insect midgut, where it binds to receptors on the midgut membrane. However, the processing of the protein through solubilization and activation by proteolytic enzymes is mostly

* Author to whom correspondence should be addressed. Tel: 515-2944776. Fax: 515-294-9823/8027. E-mail: jcoats@iastate.edu. applicable to the bacterially produced protein. The bacterially produced protein is crystalline, requiring more specific conditions for solubilization, such as certain $\mathrm{pH}$ conditions. It is also a protoxin, requiring that it be shortened by proteases to an active form. The protein in transgenic crops, however, is already the truncated active form. After ingestion, the protein binds to receptors in the midgut, then becomes inserted into the membrane, creating pores, and eventually resulting in cell lysis and extensive damage to the midgut wall. Intoxicated insects stop feeding and die (2-4).

In addition to issues of protein processing, the presence or absence of the appropriate receptors is believed to play a role in the specificity of the mode of action of the Bt proteins. However, there has been debate as to the nature of the receptor(s) in the insect midgut, and it is still uncertain how the receptor-protein interaction occurs. There have been two main receptor types proposed, the cadherins or cadherin-like proteins $(5,6)$ and aminopeptidase N (7-9). Some authors hypothesize an interaction between the two types of receptors (10).

The genes encoding several of the Bt toxins have been engineered into a variety of crop plants as inherent insect protectants. These plants are generically referred to as Bt crops (i.e., Bt corn, Bt cotton, etc.). This use of Bt, through the expression of genes encoding for production of the Cry protein toxins in transgenic plants, has increased substantially in agroecosystems, especially since 1999. For example, 9.7 million ha of Bt corn (Zea mays) was planted in 1999 in the United States, compared to 2.8 million ha in 1998 (11). Worldwide, the area on which Bt corn, as a single trait or in combination 
Table 1. Cry Protein Expression Levels in Various Tissues for Selected Transgenic Crops ${ }^{a}$

\begin{tabular}{|c|c|c|c|c|c|}
\hline crop & protein & leaf $(\mu \mathrm{g} / \mathrm{g})$ & $\operatorname{root}(\mu \mathrm{g} / \mathrm{g})$ & seed $(\mu \mathrm{g} / \mathrm{g})$ & whole plant $(\mu \mathrm{g} / \mathrm{g})$ \\
\hline Bt11 corn & Cry1Ab & 3.3 & 2.2-37.0 (extractable) & 1.4 & \\
\hline Mon810 corn & Cry $1 A b$ & 10.34 & & $0.19-0.39$ & 4.65 \\
\hline corn & Cry1F & $56.6-148.9$ & & $71.2-114.8 \mu \mathrm{g} / \mathrm{g}$ total protein & 250 \\
\hline $\begin{array}{l}\text { Mon863 corn } \\
\text { cotton }\end{array}$ & $\begin{array}{l}\text { Cry } 3 \mathrm{Bb} 1 \\
\text { Cry1Ac }\end{array}$ & $\begin{array}{c}30-93 \\
2.04\end{array}$ & $3.2-6.6$ & $\begin{array}{c}49-86 \\
1.62\end{array}$ & $13-54$ \\
\hline potato & Cry3A & 28.27 & 0.39 (tuber) & & 3.3 \\
\hline
\end{tabular}

\footnotetext{
a Adapted from "Cry Protein Expression", U.S. EPA, www.epa.gov/scipoly/sap/2000/october/brad3_enviroassessment.pdf; "Cry Protein Tissue Expression", U.S. EPA http:/www.epa.gov/pesticides/biopesticides/pips/bt_brad2/3-ecological.pdf; and Bacillus thuringiensis Cry33Bb1 Protein Fact Sheet, http://www.epa.gov/oppbppd1/biopesticides/ ingredients/factsheets/factsheet_006484.htm.
}

with herbicide resistance, was grown increased from 9.8 million ha in 2001 to 12.3 million ha in 2003 to 15.0 million ha in 2004 (12-14). The global area on which Bt cotton, as a single trait or in combination with herbicide resistance, was grown increased from 4.0 million ha in 2001 to 5.7 million ha in 2003 to 7.5 million ha in $2004(12-14)$.

As the use of transgenic Bt crops continues to increase, researchers have built on previous work regarding the fate and effects of the microbial Bt toxins, which have been used commercially since the 1960s. This review will discuss the most important peer-reviewed literature on the environmental fate and effects of the Bt Cry proteins from transgenic crops. This review does not discuss resistance, horizontal gene transfer, or weediness. Literature pertaining to bacterially produced Bt products, such as Bt sprays, is included and discussed only when it provides insight into the fate or biological activity of the protein in the environment. However, the focus of this review is on the Bt proteins as they are produced by transgenic crops. There have been multiple previous reviews on various aspects of the biology of $B$. thuringiensis and the use of $\mathrm{Bt}$ toxins as insecticides. Several reviews have examined the persistence and/ or nontarget effects of the Bt proteins in the environment; however, most have focused on the microbial insecticide (i.e., refs 4 and 15). Shelton et al. (16) published an extensive review on the deployment of transgenic crops, which covered aspects of economic, ecological, and social impacts. Although this extensive review examined transgenic crops, it included only a few pages on nontarget effects and no information on the environmental fate of the Bt protein. An annotated bibliography of the Bt protein environmental fate and effects literature has been developed and is available as a database, which can be found at http://www.ent.iastate.edu/dept/research/tox/btlit/. The bibliography was created as a database with fields that include complete reference materials and a limited set of keywords. It also includes brief summaries for each paper. The database can be searched for any keyword, author, or journal title. The entries for the papers that were deemed to be most critical to the issues of environmental fate and effects of Bt include commentary on the methods and results.

\section{ENVIRONMENTAL FATE}

Protein Expression Levels in Crops. The simplest route of exposure to the $\mathrm{Bt}$ proteins is through direct consumption of the leaf, stalk, root, seed, or pollen of the transgenic plants. The amount of protein in the plant tissue is related to two factors, the event and the promoter. An event is the actual act of inserting the gene coding for Bt production into the genetic material of the plant. The insertion location affects where in the plant tissue the Bt protein is expressed and also the quantity in which it is expressed. The promoter tells the gene when and where to produce the Bt protein. Several promoters are used, and this also affects the quantity of Bt expression. Currently, it is difficult to control the location of insertion of the Bt gene, so the Cry proteins are expressed at various levels in different crops and in different events. There are many Bt hybrids on the market, but they are derived from only a limited few events. The data in Table 1 reflect tissue expression levels submitted to the U.S. Environmental Protection Agency (EPA) for some Bt crops (17-19). There are almost no studies available in the peerreviewed literature on changes in the expression of Bt proteins during the course of a growing season, under conditions of stress, or due to climatic changes. Fearing et al. (20) determined that the highest concentration of Bt per plant occurred at seedling stage and then decreased. However, the largest amount of protein per acre occurred at anthesis, when the plant biomass is greatest. It can be assumed that many environmental factors will affect plant protein concentrations in the field. Data on seasonal, climatic, and stress-induced changes in expression of the protein would be valuable in determining the protein concentration to which nontarget organisms may be exposed.

Soil Fate of Bt Cry Proteins. Bt proteins will be incorporated into soil with plant tissue postharvest, with sloughing of root cells, and potentially through the release of exudates from roots. Saxena and Stotzky (21) reported the presence of the protein in secretions from roots, but soil concentrations were not determined. It is uncertain if the authors' determination of toxin was due solely to released toxin or if it was also due to sloughed root cells and plant material. There are few published estimates of the amount of Bt protein that would be added to soil by transgenic crops. Sims and Ream (22) calculated that approximately $486 \mathrm{~g} / \mathrm{acre}(1174 \mathrm{~g} / \mathrm{ha})$ or $1.6 \mu \mathrm{g} / \mathrm{g}$ of soil of $\mathrm{Bt}$ protein would be added to soil from a mature transgenic cotton crop. This remains one of the few published quantitative estimates of Bt protein loads to soil, and it was based solely on inputs from above-ground plant biomass. The estimate generated by Sims and Ream is much larger than that given in the Biopesticide Registration Action Document (BRAD) for Cry1Ac cotton (18). On the basis of an assumption of 60000 plants/ acre, the BRAD estimates a load of $1.44 \mathrm{~g}$ of Cry1Ac/acre (3.56 $\mathrm{g} / \mathrm{ha})$. It is unclear why the estimates are different. Both use an assumption of 60000 plants per acre. Sims and Ream used a concentration of $34 \mu \mathrm{g} / \mathrm{g}$ of leaf tissue, but the BRAD does not give a whole plant concentration of Cry1Ac. Using the load of protein from a whole crop given in the BRAD, an estimate of soil concentration can be generated. If it is assumed that the entire mass of the crop is incorporated, and that this incorporation is into $2.242 \times 10^{6} \mathrm{~kg}$ of soil/ha (mass of soil in 1 ha to the depth of a furrow slice, $15 \mathrm{~cm}$ ), the Bt concentration in soil for a cotton crop is $1.58 \mu \mathrm{g}$ of Cry $1 \mathrm{Ac} / \mathrm{kg}$ of soil. This amount is, again, smaller than that estimated by Sims and Ream, but this is likely to be due to the difference in the calculated field load and the fact that Sims and Ream calculated their concentra- 
Table 2. Summary of Results from Selected Studies of Bt Protein Persistence in the Environment, Including Cry Protein Type, Protein Source, and Measurement Endpoint

\begin{tabular}{|c|c|c|c|c|}
\hline persistence & protein & source & endpoint & citation \\
\hline $\begin{array}{l}\mathrm{DT}_{50}<1 \text { day } \\
\mathrm{DT}_{50}<30 \text { days } \\
\text { half-lives of } 2.2,22,40 \text {, and } 46 \text { days } \\
\mathrm{DT}_{50}=1.6 \text { days (in soil) and } 15 \text { days (no soil) } \\
\mathrm{DT}_{50}=15.5 \text { days (lab) and } 31.7 \text { days (field), } \\
\quad 20-25 \% \text { of bioactivity remained after } 120 \text { days } \\
\text { insecticidal activity of extracts retained for } 6 \text { months } \\
\text { detection and insecticidal activity at termination } \\
\text { of test }-28 \text { days (Cry } 1 \mathrm{Ab} \text { ) and } 56 \text { days (Cry } 1 \mathrm{Ac} \text { ) } \\
\text { decreased to } 20 \% \text { of initial in } 60 \text { days (buried) } \\
\text { and to } 38 \% \text { of initial in } 40 \text { days (soil surface); } \\
\text { protein remained detectable postharvest through } \\
\text { following spring }\end{array}$ & $\begin{array}{l}\text { Cry1F } \\
\text { Cry1 } \mathrm{Ab} \text { and Cry1Ac } \\
\text { Cry1 } \mathrm{Ab} \text { and Cry1Ac } \\
\text { Cry1 } \mathrm{Ab} \\
\text { Cry2A } \\
\text { Btk (Cry1) } \\
\text { Cry1Ab and Cry1Ac } \\
\text { Cry1Ab }\end{array}$ & $\begin{array}{l}\text { microbial } \\
\text { microbial and cotton tissue } \\
\text { microbial and cotton tissue } \\
\text { corn tissue } \\
\text { cotton tissue } \\
\text { Dipel (sporular formulation) } \\
\text { cotton tissue } \\
\text { corn tissue }\end{array}$ & $\begin{array}{l}\text { H. virescens bioassay } \\
\text { ELISA } \\
\text { ELISA } \\
\text { H. virescens bioassay } \\
\text { H. virescens bioassay } \\
\text { M. sexta bioassay } \\
\text { ELISA and } H \text {. virescens } \\
\text { bioassay } \\
\text { ELISA }\end{array}$ & $\begin{array}{l}\text { Herman et al. (24) } \\
\text { Palm et al. (26) } \\
\text { Palm et al. (30) } \\
\text { Sims and Holden (25) } \\
\text { Sims and Ream (22) } \\
\text { Tapp and Stotzky (28) } \\
\text { Donegan et al. (27) } \\
\text { Zwahlen et al. (31) }\end{array}$ \\
\hline
\end{tabular}

tion on the basis of incorporation into the top $7.6 \mathrm{~cm}$, rather than $15 \mathrm{~cm}$. For Bt11 corn, the BRAD gives an estimated load of $0.57 \mathrm{lb} / \mathrm{acre}(638 \mathrm{~g} / \mathrm{ha})$ of Cry1Ab protein, based on an assumption of $89300 \mathrm{lb}$ of fresh corn tissue from 1 acre of corn. From this load, a concentration of $284 \mu \mathrm{g}$ of Cry $1 \mathrm{Ab} / \mathrm{kg}$ of soil is calculated in the manner described previously for Cry1Ac cotton. Although the BRAD does not give estimates of whole crop protein loads from the other Bt corn types, they can be calculated using the whole plant concentrations given in the BRAD and using the same assumption of $89300 \mathrm{lb}$ of fresh corn tissue from 1 acre of corn that was used for the Bt11 estimate. On the basis of the data shown in Table 1 for whole plant concentrations, the load calculated for Mon810 corn is $465 \mathrm{~g}$ of Cry1 Ab/ha, and the calculated soil concentration is $208 \mu \mathrm{g}$ of Cry $1 \mathrm{Ab} / \mathrm{kg}$ soil. For Mon863 corn, containing the beetle-targeted $\mathrm{Cry} 3 \mathrm{Bb} 1$ protein, the load calculated is 1301$5405 \mathrm{~g}$ of $\mathrm{Cry} 3 \mathrm{Bb} 1 / \mathrm{ha}$, and the calculated soil concentration is $580-2410 \mu \mathrm{g}$ of Cry3Bb1/kg of soil. The EPA fact sheet for corn containing the Cry1F protein gives an estimate of $20.5 \mathrm{~g}$ of Cry1F/acre (50.65 g/ha) and a concentration in soil of $23 \mu \mathrm{g}$ of Cry $1 \mathrm{~F} / \mathrm{kg}$ of soil (23).

The soil fate of the Bt protein is a key parameter governing exposure of nontarget organisms in the environment. However, conflicting results have been found in assessing Bt protein persistence. Herman et al. (24) estimated a half-life in soil for Cry1F of $<1$ day using a bioassay with tobacco budworm (Heliothis virescens). Sims and Holden (25) report a DT 50 (time to $50 \%$ dissipation) of 1.6 days for Cry $1 \mathrm{Ab}$ from corn tissue and 8.3 days for purified (bacterially produced) protein. In a 30-day persistence study, Palm et al. (26) reported an $88 \%$ soil dissipation of Cry1 Ab protein from transgenic cotton in 7 days, followed by almost no dissipation for the remaining 21 days of the study. The authors also reported that the plant-produced protein degraded at a faster rate than purified $\mathrm{Bt}$ protein in the same soil. However, this comparison may not be accurate. The initial amount of protein added to the soil was $>50$ times greater in the experiments using the transgenic protein than in those using the purified protein, and starting quantity is known to affect degradation rates in soil systems. Donegan et al. (27) observed immunological and insecticidal activity of Cry1 Ab protein for up to 28 days and of Cry1Ac protein for up to 56 days in soil. The experiments lasted only either 28 or 56 days. Tapp and Stotzky (28) found that the insecticidal activity of Bt subsp. kurstaki protein in soil remained for $>6$ months. Despite the short half-lives indicated by some of the studies, there is also evidence for a more complex dissipation process, and many studies indicate that there is a portion of active protein still present in the soil for a much longer time period. Some of the results of the studies discussed are summarized in Table 2.

Persistence in the environment can be expressed in different ways, and this affects comparisons between studies. Terms such as $\mathrm{DT}_{50}$ and half-life are used to describe the time until the amount of a substance remaining is $50 \%$ of the original amount. Strictly speaking, half-life applies only to first-order dissipation processes, but is often used in a more general manner. Persistence can also be discussed in terms of detectable residues and bioactivity. Description of detectable residues is a reference to an amount of substance that can be determined by the analytical method, but does not necessarily indicate biological activity. An example of this would be detection by biochemical methods, without concurrent use of a bioassay. Determination of persistence of biological activity requires use of a living organism to indicate toxic activity. $\mathrm{A} \mathrm{DT}_{50}$ of $1-2$ days in soil is indicative of an initially rapid rate of dissipation, although the relative roles of degradation, binding, and movement are unknown. Detectable residues after 2-6 months indicate that some finite amount of the protein lasts, in a biologically active form if detected by a bioassay or in an immunologically active form if detected by ELISA, for a considerable length of time.

In addition to differences in expressing persistence, differences in dissipation/persistence of Bt proteins in soil can also be a function of soil type, environmental conditions, the protein source (purified versus plant-produced), and the particular Cry protein examined. However, one major source of differences in the results described in the previous paragraphs was the lack of reliable, accurate, and universal analytical methods. Chemical, immunochemical, and bioassay methods have all been applied for analysis of $\mathrm{Bt}$ proteins in soil. When bioassays were performed to quantify toxin persistence in soil, they were not performed in a consistent manner. Analytical methods are discussed in more detail below.

Overall, previous studies indicate that the dissipation of $\mathrm{Bt}$ toxins in soil is generally biphasic $(24,26,28,29)$. West et al. (29) characterized the degradation of parasporal Bt crystals in soil as a short lag phase, followed by a phase of rapid degradation, with the final $10 \%$ of the toxin being degraded at much slower rates. Measuring toxin concentration using a high$\mathrm{pH}$ extraction followed by ELISA detection, Palm et al. (30) also showed a biphasic pattern of degradation for Bt kurstaki (Btk) protein added as purified protein or as transgenic cotton tissue in a series of microcosm experiments using several soils. In most of the experiments, Btk protein concentrations dropped rapidly during the first 7 days in soil. By 28 days, the amount of extractable protein remaining ranged from $<0.1$ to $85 \%$, 
depending on the particular experiment. In general, there was $10-40 \%$ of the protein remaining at 28 days. The rates of dissipation varied greatly between the experiments, due to differences in soil type and starting amounts of protein. Using an insect bioassay, Sims and Ream (22) evaluated the persistence of Btk CryIIA protein, introduced to soil in transgenic cotton (Gossypium hirsutum) tissue. They found the time required for $50 \%$ dissipation $\left(\mathrm{DT}_{50}\right)$ to be 15.5 and 31.7 days under laboratory and field conditions, respectively. However, dissipation slowed after the initial decrease in bioactivity, and $\sim 20 \%$ of the bioactivity remained at 120 days. Zwahlen et al. (31) published another field study that examined the degradation of the Bt protein within corn tissue in two different experiments. The first experiment utilized buried litter bags that contained Bt or non-Bt corn material, with no soil added inside the bag. The second experiment utilized tubular cages made from the same material as the bags, with a smaller mesh size. Soil was placed inside the tubular cages, and they were buried vertically with the surface of the soil inside the bag, level with the surface of the soil outside the bag. The Bt or non-Bt corn material was added on the surface of the soil, and an earthworm was added to each bag. The results of the two experiments indicate that the breakdown of the plant itself is an important component of the degradation process of plant-produced Bt proteins and that the protein can persist in the field for several months. Although there is high variability in the measurements of the level of protein from the first time points, the authors demonstrate that a significant percentage of the protein persists and is detectable for up to 200 days, including a winter season and a spring thaw. A statistically significant difference in protein concentration between sampling time points was observed in both experiments. The first field study showed no degradation of the protein during the winter months of December through February. However, this study, showing the slowest degradation of the protein, did not include direct interaction of the leaf matter with soil. In the second study, which included soil and the earthworm added inside the bag, the protein appeared to degrade in a steadier fashion, with $7 \%$ of the initial amount remaining after 5 months. Bt protein residues were still quantifiable after $\sim 7$ months. This apparent enhanced degradation of the protein may be attributed to enhanced degradation by increased interaction with soil microbess; however, neither field study examined the amount of protein bound in the soil, only what was measurable from the remaining plant leaf matter.

Stotzky and co-workers provide additional insights into the nature of $\mathrm{Bt}$ protein interactions with soil. In a series of reports, they demonstrated that $\mathrm{Bt}$ proteins were adsorbed to soil components (clays, humic acids) and that a portion of the adsorbed protein was not readily desorbed $(28,32-35)$. The persistence of the protein in rhizosphere soil was attributed to sorption, which reduced bioavailability to soil microorganisms that would be capable of degradation. However, the authors report that the toxins retained insecticidal activity while adsorbed to soil components (28). This body of work indicates that there is potential for longer term persistence of the protein in the soil environment and continued bioavailability to nontarget organisms, if the protein can be accessed.

Analytical Methods. Although several methods have been proposed and used for the quantitative analysis of Bt protein, none of the current methods provide adequate quantification of Bt protein in natural soils. As a result, bioassays have commonly been used for qualitative and quantitative analyses $(25,36,37)$ and are based on adding the matrix to be measured (e.g., soil with toxin added) to the food of a target insect (for Cry1 and
Cry2 proteins, often Heliothis virescens or Ostrinia nubilalis). The toxic response is compared to the response generated from a known toxicity curve, generated with purified protein in the diet, to obtain a concentration. This technique provides a measurement of the active protein and does not require the protein to be extracted from the matrix. However, the method may not provide a high degree of accuracy because it will be adversely affected by the presence of other toxins in the matrix when field soils are used. Additionally, the bioassays employed as analytical methods used different insect species, even for the analysis of the same proteins, and different reporting factors. For example, the bioassay endpoint for some studies was mortality (28), for others it was growth $(22,25,38,39)$, and for still others it was a combination of growth and mortality (24). Furthermore, bioassays require the maintenance of different colonies of susceptible insects for the detection of different varieties of Bt protein. To have the most sensitive detection, the most susceptible species' must be used for each protein. Because the bioassays are expensive, time-consuming, highly subject to matrix effects, and biologically rather than chemically based, they are not an ideal analytical method.

Current chemical extraction techniques are not yet satisfactory because extraction efficiency is relatively low. There is also a high potential for false positives when chemical extraction is coupled directly to immunoassay detection without any cleanup or separation steps. Tapp and Stotzky $(40,41)$ have reported the use of flow cytometry and dot-blot techniques that can be used for the detection of Bt protein, but these techniques are qualitative and not useful to quantify low concentrations in environmental matrices. Other investigators $(42,43)$ who used HPLC with UV detection for the determination of Bt protein found interference and poor sensitivity as drawbacks. Additionally, the samples still must undergo buffer extraction and stabilization prior to analysis and still present extraction difficulties. Many investigators have turned to extraction techniques, followed by Western blot (37) or ELISA (i.e., refs 26, 30, and 44). The extraction methods used by Palm et al. (26) are typical of the state of the art for extraction from environmental matrices. Palm et al. utilized a high-pH, highsalt buffer that contained $50 \mathrm{mM}$ sodium borate $(\mathrm{pH} 10.5), 0.75$ $\mathrm{mM} \mathrm{KCl}, 0.075 \%$ Tween-20, and $10 \mathrm{mM}$ ascorbic acid. The buffer conditions of high salt and high $\mathrm{pH}$ and the addition of the surfactant Tween are somewhat analogous to the conditions inside the insect gut that are capable of solubilizing the protein from soil. Ionic interactions were found to be important by Palm et al., and the salt concentrations of the buffers were optimized to take advantage of this fact, as were the $\mathrm{pH}$ and Tween concentration. The importance of hydrophobic interactions varied with the soil type examined. Extractions were performed by mixing $0.6 \mathrm{~mL}$ of extraction buffer with $0.2-0.3 \mathrm{~g}$ of sample and homogenizing the mixture. The suspensions were centrifuged, the supernatant was removed, and the procedure was repeated twice more. All extraction steps were performed on ice. The extracts had to be diluted 10-fold prior to the ELISA detection, so that the buffer components did not interfere with detection. This reduces the sensitivity of the method. However, the limit of detection stated by Palm et al. is $0.5 \mathrm{ng}$ of extractable toxin/g of soil, which is comparable to the limit of detection of the assays for some organic pesticides. ELISA is a sensitive analysis method and provides better quantification than other methods; however, recoveries from soil are low (27-60\%), depending on soil type, and background interference is problematic in extracts obtained from soil and decomposing plant material. The overall analytical method limits of detection are 
significantly higher than the ELISA assay limit of detection when extraction efficiency is taken into account. Additionally, at least some of the toxin in soil is bioavailable to insects and exerts a toxic effect in bioassays (25), yet the current chemical techniques do not yield measurements of toxin that correlate well with the levels measured by bioassay; this may indicate that there is a relevant percentage of the toxin that is unaccounted for in the immunological methods. It is important that these differences be reconciled through advances in analytical methods.

\section{EFFECTS ON NONTARGET ORGANISMS}

Predatory Insects. One route of Bt exposure to nontarget organisms is predation upon herbivores consuming transgenic plant material. Potential deleterious effects to nontarget predators are of concern because insect predators are important in integrated pest management, preying on both target species and secondary pests, in addition to being important components of the overall ecosystem.

The main insect predator for which some hazard from $\mathrm{Bt}$ proteins has been described is the green lacewing (Chrysoperla carnea). Hilbeck et al. (45) demonstrated that $C$. carnea larvae reared on prey species that were fed transgenic, CryIAbexpressing corn leaves had a statistically greater mortality rate and development time, compared with $C$. carnea larvae reared on prey that consumed nontransformed corn leaves. However, the design of the study did not permit a distinction between direct effects from Bt toxin and indirect effects of consuming a suboptimal diet consisting only of sick or dying prey. In a second study, very high concentrations of purified Cry1 Ab (100 $\mu \mathrm{g} / \mathrm{mL}$ of diet) were used in feeding studies to assess effects on development and mortality of $C$. carnea larvae (46). Mortality was higher in the Cry1Ab diet treatments, but not when the diet was supplemented with eggs of the Mediterranean flour moth (Ephestia kuehniella). A third study was conducted in which $C$. carnea were fed larvae of a less susceptible prey species, the Egyptian cotton leafworm (Spodoptera littoralis) (47). In this experiment, the authors fed the prey a diet containing different levels $(25,50$, or $100 \mu \mathrm{g} / \mathrm{g}$ of diet) of Cry1 Ab protein or just one level $(100 \mu \mathrm{g} / \mathrm{g}$ of diet) of Cry $2 \mathrm{~A}$ protoxin. Increased mortality was seen at only the 50 and 100 $\mu \mathrm{g} / \mathrm{g}$ of diet concentrations of Cry1Ab, and the authors were able to establish a dose-response relationship. Effects on development were not consistent and were difficult to characterize. The authors reported that in bioassays with $100 \mu \mathrm{g} / \mathrm{g}$ of diet, $S$. littoralis exhibited $>40 \%$ mortality. The effects observed at the highest dose of protein may therefore be hard to separate from the effects of consuming suboptimal prey. A study by Dutton et al. (48) may corroborate the hypothesis of a preymediated effect of the protein on $C$. carnea. In this study, three different herbivores, the cherry-oat aphid (Rhopalosiphum padi), the two-spotted spider mite (Tetranychus urticae), and $S$. littoralis, were fed transgenic or isogenic corn material and assayed for their performance using the intrinsic rate of increase. Only $S$. littoralis was significantly affected. The Bt concentration in the herbivores was measured using ELISA, with T. urticae containing $2.5 \mu \mathrm{g} / \mathrm{g}$, S. littoralis $0.72 \mu \mathrm{g} / \mathrm{g}$, and $R$. padi only trace amounts of the protein. The three intoxicated larvae were then used as a food source for C. carnea. Instar-specific survival and development were affected in only the treatments fed $S$. littoralis, despite $T$. urticae having a higher measured level of protein. The authors suggest that only $S$. littoralis changes the protein to make it more toxic to $C$. carnea or that $T$. urticae degrades or deactivates the protein. Degradation of the protein by $T$. urticae is unlikely, as it would have been difficult to detect by ELISA, but it is uncertain what happens to the protein inside the guts of different herbivores, especially nonsusceptible species. It is also possible that effects were observed only in the $S$. littoralis fed treatments because, again, that prey species was somewhat susceptible to the toxin and, therefore, a poorer food source. It is also important to note that $S$. littoralis and other Lepidopteran larvae are a suitable, but not preferred, food source for $C$. carnea. This is borne out by the observation of $55.6 \%$ survivorship of $C$. carnea larvae fed $S$. littoralis reared on Bt-free isoline corn. However, the survivorship of $C$. carnea larvae fed $S$. littoralis reared on Bt corn was significantly lower at $17.7 \%$, indicating that there may be an additional negative effect of consuming the intoxicated prey source. Most recently, Romeis et al. (49) developed a method to feed Bt protein directly to larvae of $C$. carnea. Their results demonstrated that there is not a direct toxic effect of Cry1 Ab protein on $C$. carnea larvae. Taken together, these studies indicate that the initial toxic effects observed by Hilbeck were most likely due to the consumption of suboptimal prey, created by a combination of intoxication and the inherent lesser suitability of S. littoralis. Although the creation of suboptimal prey populations is an important ecological consideration, studies such as those discussed above cannot draw conclusions about what will occur in the field, and it is certain that nearly all insecticidal crop protection measures have effects on prey populations and secondary pests.

Another important insect predator in agroecosystems is the lady beetle. Nearly all of the published studies examining effects of Bt on lady beetles have used the spotted lady beetle (Coleomegilla maculata), although some of the studies submitted to the EPA have utilized the convergent lady beetle (Hippodamia convergens) (17). Several studies have been conducted in which pollen containing Cry $1 \mathrm{Ab}$ protein $(50)$ or Cry $3 \mathrm{Bb}$ protein $(51$, 52 ) was fed to larval and adult $C$. maculata. No adverse effects of the Bt protein on development or survival were observed. Lundgren and Wiedenmann (52) and Duan et al. (51) also examined adult fecundity and observed no adverse effects. Another study used the Colorado potato beetle (Leptinotarsa decemlineata), fed for $24 \mathrm{~h}$ on transgenic (Cry3A) or nontransgenic potato leaves as a food source for $C$. maculata larvae (53). Twice as many second instar larvae reached adulthood in the Bt-free treatment, but the difference was not found to be statistically significant. With the marketing of corn rootworm (Diabrotica spp.) targeted beetle-active protein toxins in corn plants, further evaluation of lady beetles and other common nontarget beetles is appropriate.

A few other insect predators have been examined in a range of studies. Newleaf Cry3 potatoes were fed to field-collected big-eyed bugs (Geocoris punctipes, Geocoris pallens), minute pirate bugs (Orius tristicolor), damsel bugs (Nabis spp.), and western tarnished plant bug (Lygus hesperus) (54). No differences in predator longevity were observed, but life spans of the field-collected individuals were highly variable. Ponsard et al. (55) reared the lepidopteran beet armyworm (Spodoptera exigua) on Cry1Ac cotton and fed them to field-collected adults of O. tristicolor, G. punctipes, Nabis sp., and assassin bugs (Zelus renardii). In contrast to other experiments, longevity for O. tristicolor and G. punctipes was reduced by 28 and $27 \%$ compared to nontransgenic fed $S$. exigua treatments. However, the methods varied somewhat among the four trials of the experiment, and it is unclear how consistent the effect was. Additionally, field-collected individuals were used, so the age distribution of the test population was unknown. In several trials of the experiments, neither the treatment nor control groups 
survived for $>10$ days. Subsequent trials did achieve longer survival times, but these data would be much more valuable if the study were repeated with populations of the same age. Furthermore, a $30 \%$ reduction in longevity may not have a significant biological effect on field populations of these predators. Al-deeb et al. (56) incorporated Dipel, which contains several Cry1 and Cry2 proteins, into the diet fed to European corn borers, $O$. nubilalis. The corn borers were then fed to fieldcollected insidious flower bugs (Orius insidiosus). No effects on mortality, growth, or development of the predator were observed. Another trophic study was conducted in which the grass thrip, Anaphothrips obscurus, fed Bt corn pollen was used as prey for a predator bug, Orius majusculus (57). No sublethal or lethal effects were observed, but it is unclear if the thrips ingest much, if any, of the Bt protein. Likewise, no adverse effects were observed in an earlier study in which Cry1 Ab pollen was fed to $O$. insidiosus (50).

Parasitoid Wasps. A limited number of studies have examined the effects of Bt proteins on parasitoids that utilize herbivorous hosts feeding on transgenic plants. Studies were submitted to the EPA demonstrating no adverse effects on the parasitoid wasp Brachymeria intermedia when fed $20 \mathrm{mg} / \mathrm{kg}$ $\mathrm{Cry} 1 \mathrm{Ab}$ in diet or on the jewel wasp (Nasonia vitripennis), another parasitoid, when fed purified Btk at very high doses (17). In the peer-reviewed literature, Salama and Zaki (58) observed reduced emergence and development of the parasitoid wasp (Zele chlorophthalmus) reared on Bt-fed S. littoralis. This is not entirely unexpected, as $S$. littoralis is somewhat susceptible to Bt protein, and the parasite may not have been able to develop in the intoxicated host due to its reduced fitness. In another study, performance of the diamondback moth parasitoid (Cotesia plutellae) was investigated in Bt-resistant and -susceptible host diamondback moths (Plutella xylostella) that were fed Bt oilseed rape (Brassica napus) (59). The parasitoid was unable to develop normally on susceptible $P$. xylostella that had consumed Bt rape. However, the authors demonstrated, using choice tests, that the parasitoids were less likely to choose the susceptible larvae. This effect was probably due to the reduction in herbivore-induced volatile compounds, used by the parasitoid females to locate hosts, in the treatments in which $P$. xylostella was intoxicated by the Bt protein. This study was exceptional in its consideration of both toxicity and behavioral components of the ecological effect. In another study using transgenic oilseed rape, Schuler et al. (60) observed no significant adverse effect on the ability of the parasitoid wasp Diaeretiella rapae to control its green peach aphid (Myzus persicae) host. However, not all analyses in this study are statistically rigorous. In the experimental design, the authors placed multiple rape plants in four cages. Two of the cages received parasitoids and two of the cages did not. The authors analyzed the experiment with parasitoids or no-parasitoids as two of the treatments. Because the parasitoids were added to each cage as a whole, the cages were the experimental unit. For those analyses that utilized the treatments parasitoids versus no-parasitoids, the analysis should have counted only two experimental units. Furthermore, mummies were found in one of the cages that was intended to be in the no-parasitoid treatment, and these data were removed from the analysis. This means that there was only one cage (one experimental unit) of the no-parasitoid treatment, further reducing the degrees of freedom of the analyses. Because of these problems with properly defining $n$ for some of the statistical analyses, it is uncertain if the conclusions are accurate.

Nontarget Lepidoptera. The toxicity of plant-produced Bt proteins to butterflies has been widely discussed and published (see annotated bibliography). It was not surprising that the $\mathrm{Bt}$ protein represented a hazard to butterflies, because the toxin targets lepidopteran insects; however, the amount of research performed was in large part driven by extensive concern in the public sector. Initial laboratory studies indicated that there was a hazard to the monarch butterfly (Danaus plexippus) larvae that consumed pollen containing high levels of Bt protein (61, 62). In 2001, a series of studies were published that examined pollen deposition, spatial and temporal overlap of pollen and monarchs, and the sensitivity of larvae to the Bt corn pollen (63-67). Data from these studies were utilized in a probabilistic risk assessment approach in an additional paper, which concluded that there was negligible risk to monarch populations from Bt corn pollen (68). Because of concern about potential sublethal effects on monarch larvae due to consumption of $\mathrm{Bt}$ pollen, this risk assessment was further updated to incorporate data on the long-term exposure to Bt pollen (69). The conclusion was that there would be only $0.6 \%$ additional mortality due to low level of exposure of larvae to Bt pollen. A second risk assessment based on a screening-level approach with conservative estimates of exposure and toxicity also determined a likelihood of low risk to monarchs (70). A question had also been raised about the potential toxicity of Bt anthers to monarch larvae. Anderson et al. (71) examined the effect of feeding on milkweed leaves contaminated with $\mathrm{Bt}$ anthers and found adverse effects at densities of anther $>0.3$ anther/cm ${ }^{2}(\sim 15$ anthers/leaf). However, in a field survey, the peak level of anther deposition was found to be $\sim 3-5$ anthers per leaf. A caged field exposure study was conducted with monarch larvae at these densities, and no adverse effects were observed. The potential toxicity to another nontarget butterfly, the black swallowtail (Papilio polyxenes), was examined in field studies. There was sublethal toxicity observed in one study, but this was due to pollen from Event 176, which has been discontinued for use (72). In a second study, using Mon810 (Cry1Ab protein), there were no adverse effects on the larvae of $P$. polyxenes observed, even when they were fed leaves coated with pollen at densities far exceeding the highest density seen in the field (63). Although the monarch and black swallowtail butterflies do not appear to be at risk from Bt pollen, any susceptible lepidopteran species that has a high likelihood of exposure to $\mathrm{Bt}$ pollen may be at risk. Endangered butterflies are of special concern, and the EPA has examined that possibility in a limited manner (17); however, study of the impact of Bt crops on endangered species of lepidopterans has been limited.

Soil Organisms. In light of the environmental fate of the $\mathrm{Bt}$ proteins, soil organisms are likely to be exposed to the protein in decomposing plant material that is incorporated into the soil matrix. There is potential for long-term exposure due to seasonlong expression of the proteins and the persistence of active protein in the soil. As discussed previously, the proteins may be released into soil with exudates or sloughed plant material throughout the growing season. Potentially, the protein could also reach the soil through shedding of leaf material and pollen, in addition to the postharvest input of plant residue incorporation. Most studies of soil organisms have used the red wiggler earthworm Eisenia fetida (Oligocheate) or the springtail Folsomia candida (Collembola) (73) and were most often conducted under artificial conditions using Bt protein isolated from Escherichia coli instead of Bt toxin directly from the transgenic crop. Although studies with purified protein help to provide insight into potential effects, their ecological relevancy is probably low. For example, Sims and Martin (74) fed four Bt proteins to two springtail species, F. candida and Xenylla grisea, 
incorporated into a diet of baker's yeast. No adverse effects were observed, but it is unclear if the protein was consumed by the test organisms. The route of exposure was ecologically unrealistic, as any possible effect on collembolans would likely occur during their participation in the breakdown of plant residues. Collembola often do not even feed on the plant material, but rather would consume fungi growing on the decaying plant material. Another study used transgenic plants expressing Cry1Ac (75). No adverse effects on $F$. candida and an oribatid mite (Oppia nitens) were observed. This study was a more realistic reflection of ecological effects because it used Bt or non-Bt plant material and soil rather than purified protein mixed with yeast. Saxena and Stotzky (76) reported no effect on common earthworms (Lumbricus terrestris) in addition to nematodes, protozoa, and bacteria after 40 days in soil that had been planted to or amended with plant material from $\mathrm{Bt}$ (Cry1Ab) corn. Growth was used as one endpoint for the assessment of the effects on the earthworm; however, in this experiment, growth was probably not an appropriate endpoint because the individuals used were already large, with fully developed clitella, and less likely to exhibit sensitive changes in growth. Exposure of juveniles would provide a more appropriate growth endpoint.

Soil microorganisms may also be exposed directly to $\mathrm{Bt}$ proteins. In addition to the study discussed previously (76), Donegan et al. (27) found that two of three Btk cotton lines tested caused an increase in total bacterial and fungal populations, in soil incubation experiments lasting 28 or 56 days. The authors suggest that this was due to unintended changes brought on by the genetic manipulation, not the protein itself. However, this raises the question of the necessity to consider the transgenic plant as a whole, and not just the equivalent of the isogenic plant plus the Bt protein. In another study, Donegan et al. (77) saw minimal differences in total microbial and fungal populations, fungal species diversity, and plant pathogen levels in $\mathrm{Bt}$ transgenic potato fields, microbial Bt treated fields, and fields treated with insecticides. Monitoring occurred periodically during a growing season of 98 days.

Nontarget Invertebrate Field Studies. Ultimately, effects observed in the laboratory have to be related to actual effects in the field. Unfortunately, field studies are often more difficult to draw conclusions from, due to their increased complexity. A few higher quality field studies have been published, and data from field studies have also been submitted to the EPA (17). Pilcher et al. (50) conducted a field survey of predator populations and found no significant detrimental effects of Cry1 Ab corn. Orr and Landis (78) examined the effect of $\mathrm{Cry} 1 \mathrm{Ab}$ corn on the predators and parasites of the European corn borer and found no effect of corn type. Lozzia (79) made field evaluations of nontarget arthropods in fields planted to Event 176 (Cry1Ab) and isogenic corn. Specifically, the biodiversity and structure of assemblages of ground beetles (Carabidae) were examined. No significant differences between corn types were found in any of the indices investigated. Although the diversity of Carabidae was low for both corn types, this type of study would be interesting in a corn variety expressing a Cry3 protein that targets beetles. Riddick et al. (80) monitored numbers of Lebia grandis, a predatory ground beetle that specializes on Colorado potato beetle, and $C$. maculata in fields planted with various mixtures of nontransgenic and transgenic potatoes. Fields contained 100, 70, 30, or 0 percent transgenic potatoes expressing Cry $3 \mathrm{~A}$. The numbers of $C$. maculata were not affected by treatment, but the numbers of $L$. grandis were significantly smaller in transgenic and mixed fields. The authors opine that $L$. grandis probably moved out of the transgenic fields due to a lack of prey, but this was not tested. This paper further illustrates the importance of considering behavior in assessments of risk and for a contextual grounding of the experiments conducted. In another study using Cry3A potatoes, Reed et al. (81) thoroughly monitored the field populations of beneficial insects and secondary pests in treatments of transgenic potatoes, microbial Bt formulations, and several types of conventional insecticides. The Bt treatments had higher populations of both beneficials and secondary pests than the conventional insecticide treatments.

Mammals, Birds, Fish, and Aquatic Invertebrates. Terrestrial vertebrates will assuredly be exposed to Bt proteins, both through consumption of plant material by herbivores and through consumption of insect herbivores by predators such as birds and small mammals. However, there is not much reason to expect toxicity to these organisms. The normal mode of toxic action for the proteins is very unlikely to occur in the vertebrate digestive system, and the protein has been used in direct testing with mammals $(17,82,83)$, and birds (17) with no adverse effects reported.

Fish are also not susceptible to the Bt proteins (17). More importantly, fish and other aquatic organisms are not likely to be exposed to the protein through its expression in crop plants. The main route of exposure for aquatic organisms would be through aerial deposition of pollen or runoff transport of soilbound Bt residue and crop material, because the protein is likely to bind to soil components rather than leach to groundwater. Saxena et al. (84) reported the potential leaching of Bt protein, from both purified protein and transgenic plant sources, through a soil column. The amount of Bt protein leached was quantified by measuring total protein via the Lowry method and comparing the values for the control and Bt-treated columns. There was no direct measurement of the amount of Bt protein leached. The leachates were assayed immunologically and with bioassay; the presence of $\mathrm{Bt}$ protein was confirmed in this manner. Detection and larvicidal activity decreased rapidly with time, indicating that the protein is not leached for a long period. The remaining protein is more likely bound to the soil, as is indicated by work discussed previously. Nontarget aquatic invertebrates have been studied using the bacterial formulations of $\mathrm{Bt}$ israelensis, because it is widely used for control of mosquito larvae. A group of studies investigating the toxicity of $\mathrm{Bt}$ kurstaki or Bt israelensis to a wide variety of nontarget species found very few adverse effects, limited to only a few species $(85-88)$.

\section{CONCLUSIONS}

The introduction and proliferation of transgenic crops in agroecosystems present a unique challenge in determining or predicting the environmental fate and effects of pesticides or other products incorporated in these crops. Previous methods used to investigate the fate and effects of conventional pesticides are not entirely adequate or appropriate for determining these same parameters for incorporated protectants from transgenic crops. The widespread adoption of Bt crops represents a shift in how insect control is conducted and should be investigated with the ecology of the agroecosystem in mind. For example, bioassays have commonly used purified proteins rather than the plant material itself, resulting in an unrealistic exposure scenario. Most currently used conventional pesticides have known, relatively short half-lives, are often effective immediately after application, and induce immediate acute effects to target and nontarget organisms. In contrast, transgenic Bt crops represent 
a new method of delivery for an insect control agent. They express the protein as an incorporated component of the plant itself throughout most of the growing season (89-91) and have a greater potential for season-long exposure due to their continuous presence in the plant. Additionally, incorporation into the plant will have an effect on the dissipation of the $\mathrm{Bt}$ proteins in the environment.

The environmental fate of $\mathrm{Bt}$ is still not well described. Degradation of Bt toxin in decomposing plant material after harvest is not well understood, with a great variability in the observed results, even within the same study $(25-27,30,31)$. The study by Zwahlen et al., for example, may describe a longterm dissipation curve of $\mathrm{Bt}$ protein in buried plant material, but the variability in the initial data points makes this more difficult to interpret. The process of degradation of plantincorporated $\mathrm{Bt}$ is different from the degradation of purified protein, involving macrofaunal and microbial decomposition of plant material before Bt proteins interact directly with soil. There is difficulty in analyzing Bt proteins in soil and other complex environmental matrices and, as a result, the presence and persistence of the plant-produced Bt proteins is currently more uncertain in comparison to many conventional insecticides. For these reasons, accurate and specific analytical methods are needed to better understand the environmental fate of plantproduced toxins. The lack of adequate analytical techniques currently available for analysis of environmental concentrations of $\mathrm{Bt}$ proteins has led to a shortage of reliable, accurate data for the estimation of environmental exposure concentrations. Additionally, improved analytical methods will help to better explain the dissipation curve resulting in short half-lives but apparent persistence of some portion of the protein for a long time.

In addition, the examination of ecological impacts of Bt toxins to nontarget organisms is still in need of ecological studies that relate estimated $\mathrm{Bt}$ toxin concentrations in the environment to the responses of representative elements of the biota. This lack of a quantitative chemical or biochemical assay is preventing the development of accurate estimates of exposure of organisms to the protein in the agroecosystem.

The lack of standardized bioassays for the transgenic crop system, the lack of taxonomic diversity tested, and the short duration and artificial conditions of many of the toxicity tests previously conducted represent additional areas that can be improved to further our understanding of the effect of Bt proteins on the agroecosystems. Many of the studies that have been conducted were for regulatory purposes and have not been peerreviewed or published (17). It can often be difficult for the average reader to find these data, and the information given in the BRADs often do not include detailed descriptions of methodology. For several groups of nontarget organisms, the existing results are still somewhat conflicting, unclear, or incomplete.

The soil ecosystem is of particular interest because soil organisms are highly likely to have at least some exposure to Bt proteins, especially with the increasing use of crops targeted at corn rootworms (e.g., Cry3 proteins). Detritivorous organisms, such as isopods, worms, mites, microbes, some beetles, and springtails, are likely to be exposed to Bt proteins in the process of degrading $\mathrm{Bt}$ crop residue. One concern with respect to nontarget effects in the soil system is that, in general, chronic effects have not been well documented in the published literature Although nontarget effects on several soil organisms have been investigated, the taxonomic diversity has been limited, many of the tests were ecologically unrealistic, and very few of the tests examined potential chronic effects.

Overall, the most important needs for the investigation of Bt-producing transgenic crops are improved chemical or biochemical analytical methods and examination of effects that come from an ecological perspective and are viewed in a realistic context. There are many questions still to be examined about the dissipation of the protein in the soil environment, including metabolism of the proteins. The determination of nontarget effects is still lacking in some areas because many of the studies conducted were ecologically unrealistic. Probably as an extension of past bioassays with agrochemicals, the protein has often been treated like a pesticide and mixed with a diet or in a soil matrix. Although this method might pose a "worst-case" scenario, it is not a realistic model of exposure and may overlook effects that are associated with the delivery of the toxin as a component of a transgenic plant. The best studies have come from a perspective that considers ecological interactions. One example is the study by Schuler et al. (59), discussed previously, in which a behavioral assessment led to a conclusion of lesser risk than initial hazard studies indicated. Another example is the series of studies involving monarch butterflies, previously discussed, in which many ecological and population factors were eventually considered and quantified.

Finally, it is very important for future studies to compare the effects of the new products to the effects of those insecticides currently deemed to be acceptable. Comparisons between the effects of a transgenic crop and the usage of conventional insecticides are not common in the literature discussed here. Thus far, in the cases when this comparison has been made (i.e., ref 81), transgenic crops have generally been found to be more protective of beneficial insects and secondary pests. It is important for studies aimed at assessing risk to be placed within the context of the agroecosystem, including the current conventional pest control measures.

\section{ACKNOWLEDGMENT}

We thank Jason Belden for help in reviewing papers in the annotated bibliography and Matt Westgate for creation of the bibliography Website.

\section{LITERATURE CITED}

(1) Flexner, J. L.; Lighthart, B.; Croft, B. A. The effects of microbial pesticides on non-target, beneficial arthropods. Agric. Ecosyst. Environ. 1986, 16, 203-254.

(2) Gill, S. S.; Cowles, E. A.; Pietrantonio, P. V. The mode of action of Bacillus thuringiensis endotoxins. Annu. Rev. Entomol. 1992, 37, 615-636.

(3) Grochulski, P.; Masson, L.; Borisova, S.; Pusztai-Carey, M.; Schwartz, J. L.; Brousseau, R.; Cygler, M. Cry1A(a) insecticidal toxin: crystal structure and channel formation. J. Mol. Biol. 1995, 254 (3), 447-464.

(4) Aronson, A. I.; Shai, Y. Why Bacillus thuringiensis insecticidal toxins are so effective: unique features of their mode of action. FEMS Microbiol. Lett. 2001, 195, 1-8.

(5) Dorsch, J. A.; Candas, M.; Griko, N. B.; Maaty, W. S. A.; Midboe, E. G.; Vadlamudi, R. K.; Bulla, L. A., Jr. Cry 1A toxins of Bacillus thuringiensis bind specifically to a region adjacent to the membrane-proximal extracellular domain of $\mathrm{Bt}-\mathrm{R}_{1}$ in Manduca sexta: involvement of a cadherin in the entomopathogenicity of Bacillus thuringiensis. Insect Biochem. Mol. Biol. 2002, 32, 1025-1036.

(6) Xie, R.; Zhuang, M.; Ross, L. S.; Gomez, I.; Oltean, D. I.; Bravo, A.; Soberon, M.; Gill, S. S. Single amino acid mutations in the cadherin receptor from Heliothis virescens affect its toxin binding ability to Cry1A toxins. J. Biol. Chem. 2005, 280 (9), 84168425 . 
(7) Knight, P. J.; Crickmore, N.; Ellar, D. J. The receptor for Bacillus thuringiensis $\operatorname{Cry} 1 \mathrm{~A}(\mathrm{c}) \delta$-endotoxin in the brush border membrane of the lepidopteran Manduca sexta is aminopeptidase N. Mol. Microbiol. 1994, 11, 429-436.

(8) Sangadala, S.; Walters, F. S.; English, L. H.; Adang, M. J. A mixture of Manduca sexta aminopeptidase and phosphatase enhances Bacillus thuringiensis insecticidal Cry1A(c) toxin binding and $86 \mathrm{Rb}(+)-\mathrm{K}(+)$ efflux in vitro. J. Biol. Chem. 1994, 269, 10088-10092.

(9) Luo, K.-E.; Sangadala, S.; Masson, L.; Mazz, A.; Brousseau, R.; Adang, M. J. The Heliothis virescens $170 \mathrm{kDa}$ aminopeptidase function as "receptor A" by mediating specific Bacillus thuringiensis Cry1A $\delta$-endotoxin binding and pore formation. Insect Biochem. 1997, 27, 735-743.

(10) Hossain, D. M.; Shitomi, Y.; Moriyama, K.; Higuchi, M.; Hayakawa, T.; Mitsui, T.; Sato, R.; Hori, H. Characterization of a novel plasma membrane protein, expressed in the midgut epithelia of Bombyx mori, that binds to Cry1A toxins. Appl. Environ. Microbiol. 2004, 70 (8), 4604-4612.

(11) Obrycki, J. J.; Losey, J. E.; Taylor, O. R.; Jesse, L. C. H. Transgenic insecticidal corn: Beyond insecticidal toxicity to ecological complexity. BioScience 2001, 51, 353-361.

(12) James, C. Global Status of Commercialized Transgenic Crops: 2002; ISAAA Brief 27; ISAAA: Ithaca, NY, 2002.

(13) James, C. Global Status of Commercialized Transgenic Crops: 2003; ISAAA Brief 30; ISAAA: Ithaca, NY, 2003.

(14) James, C. Global Status of Commercialized Transgenic Crops: 2004; ISAAA Brief 32; ISAAA: Ithaca, NY, 2004.

(15) Addison, J. A. Persistence and nontarget effects of Bacillus thuringiensis in soil: a review. Can. J. For. Res. 1993, 23, 23292342.

(16) Shelton, A. M.; Zhao, J.-Z.; Roush, R. T. Economic, ecological, food safety, and social consequences of the deployment of Bt transgenic plants. Annu. Rev. Entomol. 2002, 47, 845-881.

(17) U.S. Environmental Protection Agency Office of Pesticide Programs. Biopesticide Registration Action Document; 2000; www. epa.gov/scipoly/sap/2000/october/brad3_enviroassessment.pdf.

(18) U.S. Environmental Protection Agency Office of Pesticide Programs. Biopesticides Registration Action Document-Bacillus thuringiensis Plant-Incorporated Protectants; 2001; http:// www.epa.gov/pesticides/biopesticides/pips/bt_brad2/3-ecological.pdf.

(19) U.S. Environmental Protection Agency Office of Pesticide Programs. Bacillus thuringiensis Cry3Bb1 Protein and the Genetic Material Necessary for its Production (Vector ZMIR13L) in Event MON863 Corn Fact Sheet; 2003.

(20) Fearing, P. L.; Brown, D.; Vlachos, D.; Meghji, M.; Privalle, L. Quantitative analysis of Cry1A(b) expression in Bt maize plants, tissues, and silage and stability of expression over successive generations. Mol. Breed. 1997, 3, 169-197.

(21) Saxena, D.; Stotzky, G. Insecticidal toxin from Bacillus thuringiensis is released from roots of trangenic $B t$ corn in vitro and in situ. FEMS Microbiol. Ecol. 2000, 33, 35-39.

(22) Sims, S. R.; Ream, J. E. Soil inactivation of the Bacillus thuringiensis subsp. kurstaki CryIIA insecticidal protein within transgenic cotton tissue: laboratory and field studies. J. Agric. Food Chem. 1997, 45, 1502-1505.

(23) U.S. Environmental Protection Agency Office of Pesticide Programs. Pesticide Fact Sheet: Bacillus thuringiensis subspecies Cry $1 F$ Protein and the Genetic Material Necessary for Its Production (Plasmid Insert PHI 8999) in Corn; 2001; http://www. epa.gov/oppbppd1/biopesticides/ingredients/factsheets/ factsheet_006484.htm.

(24) Herman, R. A.; Wolt, J. D.; Halliday, W. R. Rapid degradation of the Cry1F insecticidal crystal protein in soil. J. Agric. Food Chem. 2002, 50, 7076-7078.

(25) Sims, S. R.; Holden, L. R. Insect bioassay for determining soil degradation of Bacillus thuringiensis subsp. kurstaki CryIA(b) protein in corn tissue. Environ. Entomol. 1996, 25, 659-664.
(26) Palm, C. J.; Donegan, K.; Harris, D.; Seidler, R. J. Quantification in soil of Bacillus thuringiensis var. kurstaki $\delta$-endotoxin from trangenic plants. Mol. Ecol. 1994, 3, 145-151.

(27) Donegan, K. K.; Palm, C. J.; Fieland, V. J.; Porteous, L. A.; Ganio, L. M.; Schaller, D. L.; Bucao, L. Q.; Seidler, R. J. Changes in levels, species, and DNA fingerprints of soil microorganisms associated with cotton expressing the Bacillus thuringiensis var kurstaki endotoxin. Appl. Soil Ecol. 1995, 2, 111-124.

(28) Tapp, H.; Stotzky, G. Persistence of the insecticidal toxin from Bacillus thuringiensis subsp. kurstaki from soil. Soil Biol. Biochem. 1998, 30 (4), 471-476.

(29) West, A. W.; Burges, H. D.; White, R. J.; Wyborn, C. H. Persistence of Bacillus thuringiensis parasporal crystal insecticidal activity in soil. J. Invertebr. Pathol. 1984, 44, 128-133.

(30) Palm, C. J.; Schaller, D. L.; Donegan, K. K.; Seidler, R. J. Persistence in soil of transgenic plant produced Bacillus thuringiensis var. kurstaki delta-endotoxin. Can. J. Microbiol. 1996, $42,1258-1262$.

(31) Zwahlen, C.; Hilbeck, A.; Gugerli, P.; Nentwig, W. Degradation of the Cry $1 \mathrm{Ab}$ protein within the transgenic Bacillus thuringiensis corn tissue in the field. Mol. Ecol. 2003, 12, 765-775.

(32) Venkateswerlu, G.; Stotzky, G. Binding of the protoxin and toxin proteins of Bacillus thuringiensis subsp. kurstaki on clay minerals. Curr. Microbiol. 1992, 25, 1-9.

(33) Tapp, H.; Calamai, L.; Stotzky, G. Adsorption and binding of the insecticidal proteins from Bacillus thuringiensis subsp. kurstaki and subsp. tenebrionis on clay minerals. Soil Biol. Biochem. 1994, 26, 663-679.

(34) Tapp, H.; Stotzky, G. Insecticidal activity of the toxins from Bacillus thuringiensis subspecies kurstaki and tenebrionis adsorbed and bound on pure and soil clays. Appl. Environ. Microbiol. 1995, 61 (5), 1786-1790.

(35) Koskella, J.; Stotzky, G. Microbial utilization of free and claybound insecticidal toxins from Bacillus thuringiensis and their retention of insecticidal activity after incubation with microbes. Appl. Environ. Microbiol. 1997, 63 (9), 3561-3568

(36) Beegle, C. C. Bioassay methods for quantification of the active ingredient percentage for Bacillus thuringiensis products. In Analytical Chemistry of Bacillus thuringiensis; Hickle, L. A., Fitch, W. L., Eds.; American Chemical Society: Washington, DC, 1990; pp 14-21.

(37) Sims, S. R.; Berberich, S. A.; Nida, D. L.; Segalini, L. L.; Leach, J. N.; Ebert, C. C.; Fuchs, R. L. Analysis of expressed proteins in fiber fractions from insect-protected and glyphosate-tolerant cotton varieties. Crop Sci. 1996, 36, 1212-1216.

(38) Herman, R. A.; Evans, S. L.; Shanahan, D. M.; Mihaliak, C. A.; Bormett, G. A.; Young, D. L.; Buehrer, J. Rapid degradation of Cry1F $\delta$-endotoxin in soil. Environ. Entomol. 2001, 30 (4), 642-644

(39) Herman, R. A.; Scherer, P. N.; Wolt, J. D. Rapid degradation of a binary, PS149B1, $\delta$-endotoxin of Bacillus thuringiensis in soil, and a novel mathematical model for fitting curve-linear decay. Environ. Entomol. 2002, 31 (2), 208-214.

(40) Tapp, H.; Stotzky, G. Monitoring the insecticidal toxins from Bacillus thuringiensis in soil with flow cytometry. Can. J. Microbiol. 1997, 43, 1074-1078.

(41) Tapp, H.; Stotzky, G. Dot blot enzyme-linked immunosorbent assay for monitoring the fate of insecticidal toxins from $\mathrm{Bt}$ in soil. Appl. Environ. Microbiol. 1995, 61, 602-609.

(42) Wittwer, L.; Colburn, D.; Hickle, L. A.; Sambandan, T. G. Development of a high-performance liquid chromatography assay for Bacillus thuringiensis var. san diego $\delta$-endotoxin. In Analytical Chemistry of Bacillus thuringiensis; Hickle, L. A., Fitch, W. L., Eds.; American Chemical Society: Washington, DC, 1990; pp 70-77.

(43) Yamamoto, T. Identification of entomocidal toxins of Bacillus thuringiensis by high-performance liquid chromatography. In Analytical Chemistry of Bacillus thuringiensis; Hickle, L. A., Fitch, W. L., Eds.; American Chemical Society: Washington, DC, 1990; pp 46-60. 
(44) Sims, S. R.; Berberich, S. A. Bacillus thuringiensis CryIA protein levels in raw and processed seed of transgenic cotton: Determination using insect bioassay and ELISA. J. Econ. Entomol. 1996, 89 (1), 247-251.

(45) Hilbeck, A.; Baumgartner, M.; Fried, P. M.; Bigler, F. Effects of transgenic Bacillus thuringiensis corn-fed prey on mortality and developmental time of immature Chrysoperla carnea (Neuroptera: Chrysopidae). Environ. Entomol. 1998, 27, 480-487.

(46) Hilbeck, A.; Moar, W. J.; Pusztai-Carey, M.; Filippini, A.; Bigler, F. Toxicity of Bacillus thuringiensis CryIAb toxin to the predator Chrysoperla carnea (Neuroptera: Chrysopidae). Environ. Entomol. 1998, 27, 1255-1263.

(47) Hilbeck, A.; Moar, W. J.; Pusztai-Carey, M.; Fillippini, A.; Bigler, F. Prey-mediated effects of CryIA(b) toxin and protoxin and CryIIA protoxin on the predator Chrysoperla carnea. Entomol. Exp. Appl. 1999, 91, 305-316.

(48) Dutton, A.; Klein, H.; Romeis, J.; Bigler, F. Uptake of Bt-toxin in herbivores feeding on transgenic maize and consequences for the predator Chrysoperla carnea. Ecol. Entomol. 2002, 27, 441447.

(49) Romeis, J.; Dutton, A.; Bigler, F. Bacillus thuringiensis toxin has no direct effect on larvae of the green lacewing Chrysoperla carnea (Stephens) (Neuroptera: Chrysopidae). J. Insect Physiol. 2004, 50, 175-183.

(50) Pilcher, C. D.; Obrycki, J. J.; Rice, M. E.; Lewis, L. C. Preimaginal development, survival, and field abundance of insect predators on transgenic Bacillus thuringiensis corn. Environ. Entomol. 1997, 26 (2), 446-454.

(51) Duan, J. J.; Head, G.; McKee, M. J.; Nickson, T. E.; Martin, J. W.; Sayegh, F. S. Evaluation of dietary effects of transgenic corn pollen expressing Cry 3Bb1 protein on a non-target ladybird beetle, Coleomegilla maculata. Entomol. Exp. Appl. 2002, 104, 271-280.

(52) Lundgren, G. J.; Wiedenmann, N. R. Coleopteran-specific $\mathrm{Cry} 3 \mathrm{Bb}$ toxin from transgenic corn pollen does not affect the fitness of a non-target species, Coleomegilla maculata DeGeer (Coleoptera: Coccinellidae). Environ. Entomol. 2002, 31 (6), $1213-1218$

(53) Riddick, E. W.; Barbosa, P. Impact of Cry3A-intoxicated Leptinotarsa decemlineata (Coleoptera: Chrysomelidae) and pollen on consumption, development, and fecundity of Coleomegilla maculata (Coleoptera: Coccinellidae). Ann. Entomol. Soc. Am. 1998, 91 (3), 303-307.

(54) Armer, C. A.; Berry, R. E.; Kogan, M. Longevity of phytophagous heteropteran predators feeding on transgenic Btt-potato plants. Entomol. Exp. Appl. 2000, 95, 329-333.

(55) Ponsard, S.; Gutierrez, A. P.; Mills, N. J. Effect of Bt-toxin (Cry1Ac) in transgenic cotton on the adult longevity of four Heteropteran predators. Environ. Entomol. 2002, 31 (6), 11971205.

(56) Al-deeb, M. A.; Wilde, G. E.; Higgins, R. A. No effect of Bacillus thuringiensis corn and Bacillus thuringiensis on the predator Orius insidiosus (Hemiptera: Anthocoridae). Environ. Entomol. 2001, 30 (3), 625-629.

(57) Zwahlen, C.; Nentwig, W.; Bigler, F.; Hilbeck, A. Tritrophic interactions of transgenic Bacillus thuringiensis corn, Anaphothrips obscurus (Thysanoptera: Thripidae), and the predator Orius majusculus (Heteroptera: Anthocoridae). Environ. Entomol. 2000, 29 (4), 846-850.

(58) Salama, H. S.; Zaki, F. N. Interaction between Bacillus thuringiensis Berliner and the parasites and predators of Spodoptera littoralis in Egypt. Z. Angew. Entomol. 1983, 95, 425-429.

(59) Schuler, T. H.; Potting, P. J.; Denholm, I.; Poppy, M. G. Parasitoid behavior and Bt plants. Nature 1999, 400, 825-826.

(60) Schuler, T. H.; Denholm, I.; Jouanin, L.; Clark, S. J.; Clark, A. J.; Poppy, G. M. Population-scale laboratory studies of the effect of transgenic plants on non-target insects. Mol. Ecol. 2001, 10, $1845-1853$.

(61) Losey, J. E.; Rayor, L. S.; Carter, M. E. Transgenic pollen harms monarch larvae. Nature 1999, 399, 214.
(62) Hansen-Jesse, L. C.; Obrycki, J. J. Field deposition of Bt transgenic corn pollen: lethal effects on the monarch butterfly. Oecologia 2000, 125, 241-248.

(63) Zangerl, A. R.; McKenna, D.; Wraight, C. L.; Carroll, M.; Ficarello, P.; Warner, R.; Berenbaum, M. R. Effects of exposure to event 176 Bacillus thuringiensis corn pollen on monarch and black swallowtail caterpillars under field conditions. Proc. Natl. Acad. Sci. U.S.A. 2001, 98, 11908-11912.

(64) Oberhauser, K. S.; Prysby, M. D.; Mattila, H. R.; Stanley-Horn, D. E.; Sears, M. K.; Dively, G.; Olson, E.; Pleasants, J. M.; Lam, W. F.; Hellmich, R. L. Temporal and spatial overlap between monarch larvae and corn pollen. Proc. Natl. Acad. Sci. U.S.A. 2001, 98, 11913-11918.

(65) Pleasants, J. M.; Hellmich, R. L.; Dively, G. P.; Sears, M. K.; Stanley-Horn, D. E.; Mattila, H. R.; Foster, J. E.; Clark, T. L.; Jones, G. D. Corn pollen deposition on milkweeds in and near cornfields. Proc. Natl. Acad. Sci. U.S.A. 2001, 98, 11919-11924.

(66) Hellmich, R. L.; Siegfried, B. D.; Sears, M. K.; Stanley-Horn, D. E.; Daniels, M. J.; Mattila, H. R.; Spencer, T.; Bidne, K. G.; Lewis, L. C. Monarch larvae sensitivity to Bacillus thuringiensispurified proteins and pollen. Proc. Natl. Acad. Sci. U.S.A. 2001, 98, 11925-11930.

(67) Stanley-Horn, D. E.; Dively, G. P.; Hellmich, R. L.; Mattila, H. R.; Sears, M. K.; Rose, R.; Jesse, L. C. H.; Losey, J. E.; Obrycki, J. J.; Lewis, L. Assessing the impact of Cry1Ab-expressing corn pollen on monarch butterfly larvae in field studies. Proc. Natl. Acad. Sci. U.S.A. 2001, 98, 11931-11936.

(68) Sears, M. K.; Hellmich, R. L.; Stanley-Horn, D. E.; Oberhauser, K. S.; Pleasants, J. M.; Mattila, H. R.; Siegfried, B. D.; Dively, G. P. Impact of Bt corn pollen on monarch butterfly populations: A risk assessment. Proc. Natl. Acad. Sci. U.S.A. 2001, 98, 11937-11942.

(69) Dively, G. P.; Rose, R.; Sears, M. K.; Hellmich, R. L.; StanleyHorn, D. E.; Calvin, D. D.; Russo, J. M.; Anderson, P. L. Effects on monarch butterfly larvae (Lepidoptera: Danaidae) after continuous exposure to Cry1 $\mathrm{Ab}$-expressing corn during anthesis. Environ. Entomol. 2004, 33 (4), 1116-1125.

(70) Wolt, J. D.; Peterson, R. K. D.; Bystrak, P.; Meade, T. A screening level approach for non-target insect risk assessment: Transgenic Bt corn pollen and the monarch butterfly (Lepidoptera: Danaidae). Environ. Entomol. 2003, 32 (2), 237-246.

(71) Anderson, P. L.; Hellmich, R. L.; Sears, M. K.; Sumerford, D. V.; Lewis, L. C. Effects of Cry1Ab-expressing corn anthers on monarch butterfly larvae. Environ. Entomol. 2004, 33 (4), 11091115.

(72) Wraight, C. L.; Zangerl, A. R.; Carroll, M. J.; Berenbaum, M. $\mathrm{R}$. Absence of toxicity of Bacillus thuringiensis pollen to black swallowtails under field conditions. Proc. Natl. Acad. Sci. U.S.A. 2000, 97, 7700-7703.

(73) U.S. Environmental Protection Agency Office of Pesticide Programs. Biopesticide Fact Sheet; 1999; www.epa.gov/pesticides/ biopesticides/factsheets/fs006458t.htm.

(74) Sims, S. R.; Martin, J. W. Effect of the Bacillus thuringiensis insecticidal proteins CryIA(b), CryIA(c), CryIIA, and CryIIIA on Folsomia candida and Xenylla grisea (Insecta: Collembola). Pedobiologia 1997, 41, 412-416.

(75) Yu, L.; Berry, R. E.; Croft, B. A. Effects of Bacillus thuringiensis toxins in transgenic cotton and potato on Folsomia candida (Collembola: Isotomidae) and Oppia nitens (Acari: Oribatidae). J. Econ. Entomol. 1997, 90 (1), 113-118.

(76) Saxena, D.; Stotzky, G. Bacillus thuringiensis (Bt) toxin released from root exudates and biomass of $\mathrm{Bt}$ corn has no apparent effect on earthworms, nematodes, protozoa, bacteria, and fungi in soil. Soil Biol. Biochem. 2001, 33, 1225-1230.

(77) Donegan, K. K.; Schaller, D. L.; Stone, J. K.; Ganio, L. M.; Reed, G.; Hamm, P. B.; Seidler, R. J. Microbial populations, fungal species diversity and plant pathogen levels in field plots of potato plants expressing the Bacillus thuringiensis var. tenebrionis endotoxin. Transgenic Res. 1996, 5, 25-35. 
(78) Orr, D. B.; Landis, D. A. Oviposition of European corn borer (Lepidoptera: Pyralidae) and impact of natural enemy populations in transgenic versus isogenic corn. J. Econ. Entomol. 1997, 90 (4), 905-909.

(79) Lozzia, G. C. Biodiversity and structure of ground beetle assemblages (Coleoptera Carabidae) in Bt corn and its effects on non target insects. Boll. Zool. Agric. Bachic. 1999, 31 (1), $37-58$.

(80) Riddick, E. W.; Dively, G.; Barbosa, P. Effect of a seed-mix deployment of Cry3A transgenic and nontransgenic potato on the abundance of Lebia grandis (Coleoptera: Carabidae) and Coleomegilla maculata (Coleoptera: Coccinellidae). Ann. Entomol. Soc. Am. 1998, 91 (5), 647-653.

(81) Reed, G. L.; Jensen, A. S.; Riebe, J.; Head, G.; Duan, J. J. Transgenic Bt potato and conventional insecticides for Colorado potato beetle management: comparative efficacy and non-target impacts. Entomol. Exp. Appl. 2001, 100, 89-100.

(82) Siegel, J. P.; Shadduck, J. A.; Szabo, J. Safety of the entomopathogen Bacillus thuringiensis var. israelensis for mammals. J. Econ. Entomol. 1987, 80, 717-723.

(83) McClintock, J. T.; Schaffer, C. R.; Sjoblad, R. D. A comparative review of the mammalian toxicity of Bacillus thuringiensis-based pesticides. Pestic. Sci. 1995, 45, 95-105.

(84) Saxena, D.; Flores, S.; Stotzky, G. Vertical movement in soil of insecticidal Cry1 Ab protein from Bacillus thuringiensis. Soil Biol. Biochem. 2002, 34, 111-120.

(85) Charbonneau, C. S.; Drobney, R. D.; Rabeni, C. F. Effects of Bacillus thuringiensis var. israelensis on non-target benthic organisms in a lentic habitat and factors affecting the efficacy of the larvicide. Environ. Toxicol. Chem. 1993, 13 (2), 267279.

(86) Kreutzweiser, D. P.; Holmes, S. B.; Capell, S. S.; Eichenberg, D. C. Lethal and sublethal effects of Bacillus thuringiensis var. kurstaki on aquatic insects in laboratory bioassays and outdoor stream channels. Bull. Environ. Contam. Toxicol. 1992, 49, 252258.

(87) Eidt, D. C. Toxicity of Bacillus thuringiensis var. kurstaki to aquatic insects. Can. Entomol. 1985, 117, 829-837.

(88) Molloy, D.; Jamnback, H. Field evaluation of Bacillus thuringiensis var. israelensis as a black fly biocontrol agent and its effect on non-target stream insects. J. Econ. Entomol. 1981, 74, 314-318.

(89) Perlak, F. J.; Deaton, R. W.; Armstrong, T. A.; Fuchs, R. L.; Sims, S. R.; Greenplate, J. T.; Fischhoff, D. A. Insect resistant cotton plants. Bio/Technology 1990, 8, 939-943.

(90) Fujimoto, H.; Itoh, K.; Yamamoto, M.; Kyozuka, J.; Shimamoto, $\mathrm{K}$. Insect resistant rice generated by introduction of a modified $\delta$-endotoxin gene of Bacillus thuringiensis. Bio/Technology 1993, $11,1151-1155$.

(91) Koziel, M. G.; Beland, G. L.; Bowman, C.; Carozzi, N. B.; Crenshaw, R.; Crossland, L.; Dawson, J.; Desai, N.; Hill, M.; Kadwell, S.; Launis, K. Field performance of elite transgenic maize plants expressing an insecticidal protein derived from Bacillus thuringiensis. Bio/Technology 1993, 11, 194-200.

Received for review October 28, 2004. Revised manuscript received March 13, 2005. Accepted April 4, 2005.

JF040442K 